Journal of Animal and Veterinary Advances 9 (3): 519-521, 2010

ISSN: $1680-5593$

(C) Medwell Journals, 2010

\title{
The Milk Biochemical Parameters Having Economic Importance in Machine Milked Cows
}

\author{
${ }^{1} \mathrm{O}$. Tekelioglu, ${ }^{2} \mathrm{M}$. Cimen and ${ }^{3} \mathrm{~T}$. Bayril \\ ${ }^{1}$ Department of Mechanical Engineering, ${ }^{2}$ Department of Food Engineering, \\ Faculty of Engineering, Tunceli University, Tunceli, Turkey \\ ${ }^{3}$ DIMES Kazova Animal Farm, Tokat, Turkey
}

\begin{abstract}
This research was aimed to investigate the effect of machine milking on milk biochemical components having economic importance. In the experiment, 10 Machine Milked (MM) and 10 suckled + Hand Milked (HM) cows were used. The milk fat rates were lower for MM animals in 1st, 2nd and 4th weeks ( $<<0.05$ ). Protein and total solid rates of milks were similar for both groups during study. There was found positive correlation between milk fat and total solids $(r=0.53 ; \mathrm{p}<0.05)$, but there were no significant correlations among other milk parameters. Suckling treatment (in HM group) to increase production of milk with maximum levels of milk fat is essential for achieving the economic benefits. Producers, who utilize the MM system during lactation should expect commercial milk to be low in fat content, which may affect cheese processing characteristics.
\end{abstract}

Key words: Economic, milk biochemical parameters, machine milked, cow, solids, milk fat

\section{INTRODUCTION}

The chemical composition of milk and its physicochemical ability, which are directly linked with technological parameters, decide about its acceptance in the milk industry. Biochemical parameters from animal products have got favorable economic benefits (Cicek, 2007). Milk protein, fat and total solids have economic value because higher protein, fat and total solids lead to higher cheese yields (Hicks et al., 1985). They are therefore called economic parameters. The milk biochemical parameters having economic importance impact product development and international trade in milk components (Colemann, 2004). Recently, dairy producers and reserachers focus on maximizing economic biochemical parameters such as milk fat and protein (Cimen et al., 2007; Cimen et al., 2008a, b; Cimen and Karaalp, 2009).

Current milk pricing formulas emphasize milk fat, giving maintenance of normal milk fat test an economic advantage. However, there were not enough statements about effect of machine milking on biochemical parameters of milk during all lactation period. The studies on the milk parameters in machine milking treatment are limited. This research was aimed to investigate the effect of machine milking on economic biochemical components of milk. This is the first detailed study on economic biochemical parameters of machine milked cows.

\section{MATERIALS AND METHODS}

In the experiment, 10 Machine Milked (MM) and 10 suckled + Hand Milked (HM) cows were used. To determine milk composition, samples were obtained by hand milking for first month of early lactation. Milk samples were composites of milk collected at consecutive morning and afternoon for last day of each week. The samples were collected into plastic vials preserved with micro tabs, stored $4^{\circ} \mathrm{C}$ until analyzed for determination of parameters. The total protein of the milk was determined by Kjeldahl method $(\mathrm{N} \times 6.38)$. The milk fat was determined by Roese-Gottlieb method (Hundrieser et al., 1984). Total solids were determined by drying a known mass of milk at $102 \pm 1^{\circ} \mathrm{C}$.

All of the data are indicated as mean \pm SEM. Comparisons were done by using t-test with help of the SPSS (Norusis, 1993).

\section{RESULTS AND DISCUSSION}

Table 1-4 shows significant differences between $M M$ and $\mathrm{HM}$ animals with respect to milk fat rates. The milk fat rates were lower for MM animals in 1st, 2nd and 4th weeks $(p<0.05)$. Protein and total solid rates of milks were similar for both groups during study ( $\mathrm{p}>0.05$ ). Milk protein and total solid rates of MM and HM cows in this study are consistent with normal values for cows announced by

Corresponding Author: Oguz Tekelioglu, Department of Mechanical Engineering, Faculty of Engineering, Tunceli University, Tunceli, Turkey 
Table 1: Economic parameters of milk for first week

\begin{tabular}{|c|c|c|c|}
\hline \multirow[b]{2}{*}{ Parameters (\%) } & \multicolumn{3}{|c|}{ Animals } \\
\hline & $\mathrm{MM}$ & $\mathrm{HM}$ & $\mathrm{p}$-value \\
\hline Fat & $2.7 \pm 0.1$ & $3.3 \pm 0.2$ & $*$ \\
\hline Protein & $4.4 \pm 0.1$ & $4.6 \pm 0.2$ & NS \\
\hline Total solids & $11.8 \pm 0.4$ & $11.9 \pm 0.3$ & NS \\
\hline
\end{tabular}

Table 2: Economic parameters of milk for second week Animals

\begin{tabular}{lccc} 
& & & \\
Parameters (\%) & MM & HM & p-value \\
\hline Fat & $3.0 \pm 0.2$ & $3.6 \pm 0.2$ & $*$ \\
Protein & $3.9 \pm 0.1$ & $4.1 \pm 0.3$ & NS \\
Total solids & $11.5 \pm 0.3$ & $11.7 \pm 0.4$ & NS \\
\hline
\end{tabular}

Table 3: Economic parameters of milk for third week

\begin{tabular}{llrc}
\hline & Animals & & \\
& - & & \\
Parameters (\%) & MM & HM & p-value \\
\hline Fat & $3.1 \pm 0.3$ & $3.5 \pm 0.2$ & NS \\
Protein & $4.3 \pm 0.1$ & $4.6 \pm 0.3$ & NS \\
Total solids & $11.6 \pm 0.4$ & $11.9 \pm 0.3$ & NS \\
\hline
\end{tabular}

Table 4: Economic parameters of milk for fourth week

\begin{tabular}{llrc}
\hline & Animals & & \\
& - & & \\
Parameters (\%) & \multicolumn{1}{c}{ MM } & HM & p-value \\
\hline Fat & $3.2 \pm 0.1$ & $3.6 \pm 0.2$ & $*$ \\
Protein & $4.0 \pm 0.4$ & $4.5 \pm 0.2$ & NS \\
Total solids & $11.4 \pm 0.4$ & $11.6 \pm 0.2$ & NS \\
\hline
\end{tabular}

${ }^{*} \mathrm{p}<0.05$, NS: Not Significant

Kaneko et al. (1997). Weekly milk fat rates of MM group were found lower than normal values $(3.5 \%)$ (Kaneko et al., 1997). The milk fat rates of MM were low for economic cheese production because, milk must contain a fat percentage at least $3.2 \%$ for economic cheese (Kurt et al., 1993). We can explain to reason of low milk fat that the milking machine captures cisternal milk but not alveolar milk, where most of the fat is found (Thomas et al., 2001). Reasons for low milk fat in MM group could involve one or all of the following three physiologic mechanisms: milk ejection during machine milking does not occur, milk fat synthesis is inhibited and milk fat transfer from the alveoli to the cistern between milkings does not occur.

Marnet and Negrao (2000) have addressed the first possibility and have demonstrated that plasma oxytocin concentrations do not increase above baseline levels during machine milking of $\mathrm{MM}$ animals, which causes failure of milk ejection during milking but not during suckling, for as long as these dams remain in partial daily contact with their calves. Therefore, only the cisternal milk fraction is assumed to be available during machine milking of $\mathrm{MM}$ dams because removal of the alveolar milk fraction would require active myoepithelial contraction (Bruckmaier, 2000). It has been estimated that $>75 \%$ of the total fat yield within the udder is
Table 5: Correlation coefficients between experimental data

\begin{tabular}{llcc}
\hline Parameters (\%) & Fat (\%) & Protein (\%) & Total solids (\%) \\
\hline Fat & - & NS & $0.53^{*}$ \\
Protein & NS & - & NS \\
Total solids & $0.53^{*}$ & NS & - \\
\hline${ }^{*} p<0.05$, NS: Not Significant & &
\end{tabular}

associated with the alveolar milk fraction and thus is only obtainable, when milk ejection occurs during machine milking (Labussiere, 1969). Although, the mechanism is presently unknown, one could imagine that the stress associated with separation of MM dams from their calves might have played a role in inhibiting fat transfer.

There was found positive correlation between milk fat and total solids $(\mathrm{r}=0.53 ; \mathrm{p}<0.05)$ but there were no significant correlations among other economic milk parameters (Table 5). The relationships of the fat to total solids and solids-not-fat have been the subject of research for many investigators (Bakalor, 1958; Outlaw et al., 1993).

A decrease in milk fat percentage in MM group can directly lead to financial loss, if the milk price depends on milk fat percentage. In addition, it has been shown that a strong decrease in milk fat percentage is related to a larger and longer lasting negative energy balance for early lactation period. Suitable feeding regimes to increase production of milk with maximum levels of milk fat and protein are essential for achieving these benefits during this critic period (Mcguire et al., 1995; Samuelsson, 1996).

\section{CONCLUSION}

Producers, who utilize the MM system during early lactation should expect commercial milk to be low in fat content, which may affect cheese or other milk products processing characteristics. Further researches are needed to improve the interpretations about lactation biology in machine milking treatment considering the reasons for lower milk fat and to determine the effect of biochemical parameters having economic importance on productivity of milk and its products.

\section{ACKNOWLEDGEMENTS}

Thanks are expressed to Mr. A.R. Diren and Mr. K. Suner for financial and technical supports.

\section{REFERENCES}

Bakalor, S., 1958. Investigations on the composition of South African Milk: VII. The compositional quality of the South African city milk supply. Bulletin, 13: 377-385. 
Bruckmaier, R.M., 2000. Milk ejection during machine milking in dairy cows. Livest. Prod. Sci., 70: 121-124.

Cicek, A., 2007. The milk biochemical parameters having economic importance in non-dairy acidosis animals. Asian J. Chem., 19: 4903-4906.

Cimen, M. and M. Karaalp, 2009. The effect of restricted suckling time on milk components and sucking behavior of lambs. Arch. Tierz., 52: 299-308.

Cimen, M., M. Cetin, M. Karaalp and S. Sahin, 2008a. The effect of diet selection on plasma and milk parameters in sheep. Indian Vet. J., 85: 1312-1315.

Cimen, M., M. Karaalp and M. Elmastas, 2008b. Effect of breed and live weight on milk fat depression in sheep. Asian J. Chem., 20: 3885-3888.

Cimen, M., M. Karaalp and S. Sahin, 2007. Relationships between some blood and milk components in early lactation in non-dairy sheep. Asian J. Chem., 19: $600-606$.

Colemann, J., 2004. Conditions of Competition for Milk Protein Products in the U.S. Market. USITC Publication, Washington DC.

Hicks, C.L., J. O'leary and J. Holbrook, 1985. Effect of lecithin on cheese yield. J. Dairy Sci., 68: 1603-1607.

Hundrieser, K.E., R.M. Clark, R.G. Jensen and A.M. Ferris, 1984. A comparison of methods for determination of total lipids in human milk. Nutr. Res., 4: 21-26.

Kaneko, J.J., J.W. Harvey and M.L. Bruss, 1997. Clinical Biochemistry of Domestic Animals. 5th Edn., Academic Press, New York, pp: 39-386.
Kurt, A., S. Cakmakci and S. Caglar, 1993. Guide of Inspection and Analysis Methods in Milk and Milk Products. Agricultural Faculty Press, Erzurum, pp: 284-290.

Labussiere, J., 1969. Importance, composition Et signification des diffe rentes fractions de lait obtenues successivement au cours de la traite me' canique des brebis. Ann. Zootech., 18: 185-196.

Marnet, P.G. and J.A. Negrao, 2000. The effect of a mixed-management system on the release of oxytocin, prolactin and cortisol in ewes during suckling and machine milking. Reprod. Nutr. Dev., 40: $271-281$.

Mcguire, M.A., J.M. Griinari, D.A. Dwyer and D.E. Bauman, 1995. Role of insulin in the regulation of mammary synthesis of fat and protein. J. Dairy Sci., 78: 816-824.

Norusis, M.J., 1993. SPSS for Windows Base System Users Guide. 1st Edn., SPSS Inc., Chicago, pp: 828.

Outlaw, J., R. Knutson and B. Schwart, 1993. Minimum solids-not-fat standards for fluid milk. Dairy Markets and Policy, pp: 1-6. http:/www.cpdmp.cornell.edu/ CPDMP/Pages/Publications/Pubs/P13.pdf.

Samuelsson, B., 1996. The influence of management routines on endocrine systems involved in the control of lactation in dairy cattle. Ph.D. Thesis, Sweed. Univ. Agric. Sci. Uppsala, Sweeden.

Thomas, D.L., Y.M. Berger and B.C. Mckusick, 2001. Effects of breed, management system and nutrition on milk yield and milk composition of dairy sheep. J. Anim. Sci., 79: 16-20. 